\title{
MENINGKATKAN KEMAMPUAN KOMUNIKASI MATEMATIS SISWA MELALUI MAKE A MATCH BERBANTUAN CD PEMBELAJARAN MATERI PERSAMAAN TRIGONOMETRI SEDERHANA
}

\author{
${ }^{1)}$ Nila Ubaidah, M. ${ }^{2)}$ Abdul Basir \\ ${ }^{1)}$ Fakultas Keguruan dan Ilmu Pendidikan, Unissula Semarang; \\ nilaubaidah@unissula.ac.id \\ ${ }^{2)}$ Fakultas Keguruan dan Ilmu Pendidikan, Unissula Semarang; \\ abdulbasir@unissula.ac.id
}

\begin{abstract}
This study investigated teh effect of make a match method aided learning CD for students' mathematical communication ability on the simple trigonometric equations. This study was designed with classroom action research design. This study using students activity observvations, test students' mathematical communication ability as an istrument for data collection. The result of this study found that the implementation measures make a match aided learning $\mathrm{CD}$ in mathematics learning can help students understand the simple trigonometric equations. It can be seen on an average of mathematical communication ability test result achieved students. In the first cycle, the average result achieved at 68,40 . In the second cycle, the average learning outcomes achived is 72,31 . The average of completeness of student learning outcomes in the classical style on the first cycle is $66,67 \%$ and teh second cycle is $86,67 \%$. The average performance of students on the first cycle is 2,7 and on the second cycle is 3,2. The performnce of students, student activities in the learning process is included in effective category, the response of students towards learning is positive and in the classical completeness is achieved, then effectively be used to teach the materal simple trignometric equations.
\end{abstract}

Keywords: make a Match, Mathematical Communication Ability, Simple Trigonometry

Abstrak
Penelitian ini mengkaji tentang pengaruh make a match berbantuan CD
pembelajaran terhadap kemampuan komunikasi matematis siswa pada materi
persamaan trigonometri sederhana. Penelitian ini dirancang dengan rancangan
penelitian tindakan kelas. Penelitian ini menggunakan observasi keaktifan siswa,
hasil tes kemampuan komunikasi matematis siswa sebagai instrumen dalam
pengumpulan data. hasil penelitian ini ditemukan bahwa penerapan langkah-langkah


make a match berbantuan CD pembelajaran dalam pembelajaran matematika dapat membantu siswa memahami materi persamaan trigonometri sederhana. Hal ini dapat dilihat pada rata-rata hasil tes kemampuan komunikasi matematis yang dicapai oleh siswa. Pada siklus I, rata-rata hasil yang dicapai yaitu 68, 40. Pada siklus II, rata-rata hasil belajar yang dicapai yaitu 72,31. Rata-rata ketuntasan hasil belajar siswa secara klasikal pada siklus I yaitu $66,67 \%$ dan pada siklus II yaitu $86,67 \%$. Rata-rata kinerja siswa pada siklus I sebesar 2,7 dan pada siklus II sebesar 3,2. Kinerja siswa, aktivitas siswa dalam proses pembelajaran termasuk dalam kategori efektif, respon siswa terhadap pembelajaran adalah positip dan ketuntasan secara klasikal tercapai, maka efektif digunakan untuk mengajarkan materi persamaan trigonometri sederhana.

Kata kunci : Make a Match, Kemampuan Komunikasi Matematis, Trigonometri Sederhana.

\section{PENDAHULUAN}

Pembelajaran Make a Match merupakan suatu metode pembelajaran mencari pasangan. Siswa harus mencari pasangan kartu soal yang dimiliki sambil belajar mengenai suatu konsep atau topik dalam suasana yang menyenangkan. Dalam menentukan kartu jawaban siswa dituntut untuk menentukan jawaban atau soal dari kartu yang dipegang. Disinilah terjadi interaksi antara kelompok dan interaksi antara siswa di dalam kelompok untuk membahas kembali soal dan jawaban sehingga dengan Make a Match berbantuan $\mathrm{CD}$ pembelajaran dapat memupuk kerjasama dalam menjawab pertanyaan dengan mencocokan kartu yang ada di tangan mereka, proses pembelajaran lebih menarik dan keaktifan siswa sangat dituntut untuk mencari pasangan kartunya masing masing.

Belum adanya penggunaan $\mathrm{CD}$ pembelajaran yang memadai dalam proses pembelajaran yang sesuai dengan karakteristik siswa merupakan hambatan bagi guru matematika dalam menerapkan pembelajaran di sekolah. CD pembelajaran dipilih karena media ini memiliki ciri-ciri yang mampu meningkatkan keaktifan siswa untuk belajar yaitu antara lain bentuk dan warna menarik, membuat siswa tertarik untuk mempelajarinya serta yang paling penting dapat memperjelas konsep bagi siswa.

Kemampuan komunikasi matematis siswa masih rendah dalam pembelajaran, khususnya untuk pelajaran matematika yang abstrak. Berdasarkan pengalaman peneliti dan hasil wawancara dengan beberapa guru matematika SMA dalam studi pendahuluan menjelaskan bahwa "sikap siswa yaitu motivasi belajar matematika kurang dan cenderung malas belajar matematika di kelas" atau cepat merasa bosan dengan metode pembelajaran yang diterapkan, sehingga komunikasi matematis siswa menjadi berkurang, karena pembelajaran tidak berjalan secara efektif. Hal ini berdampak pada menurunnya prestasi belajar siswa 
baik secara individu maupun klasikal. Penurunan tersebut diakibatkan pada keaktifan siswa yang kurang terhadap pembelajaran yang berlangsung. Selain itu siswa disana cenderung bersikap individualis tetapi memiliki kemampuan akademik yang baik, sehingga sikap belajar siswa terhadap pembelajaran kurang. Penggunaan metode pembelajaran ini, diharapkan peneliti dapat menemukan pola yang lebih efektif untuk mengetahui berbagai kelebihan dan kekuatan dari metode pembelajaran ini, sehingga hasilnya dapat diterapkan pada kondisi pembelajaran yang lain.

Berdasarkan beberapa uraian di atas, peneliti tertarik untuk mengadakan penelitian tindakan kelas dengan judul: Meningkatkan Kemampuan Komunikasi Matematis Siswa Melalui Make A Match Berbantuan CD Pembelajaran Materi Persamaan Trigonometri Sederhana. Tujuan yang ingin dicapai dalam penelitian ini adalah untuk mengetahui pengaruh make a match berbantuan CD pembelajaran terhadap kemampuan komunikasi matematis siswa pada materi persamaan trigonometri sederhana.

\section{KAJIAN TEORI}

\section{Pembelajaran kooperatif Make a Match}

Make a Match merupakan bagian dari metode struktural yang menekankan pada struktur-struktur khusus yang dirancang untuk mempengaruhi pola-pola interaksi siswa. Struktur-struktur tersebut memiliki tujuan umum diantaranya untuk meningkatkan penguasaan isi akademik dan mengajarkan keterampilan sosial (Sugiyanto, 2010).

Metode Make a Match adalah teknik mencari pasangan, siswa di gabung suruh mencari pasangan dari kartu yang mereka pegang. Keunggulan teknik ini adalah siswa mencari pasangan sambil belajar mengenai suatu konsep atau topik dalam suasana yang menyenangkan. Teknik ini dapat digunakan dalam semua mata pelajaran dan untuk semua tingkatan usia anak didik Proses pembelajaran yang efisien ialah pembelajaran yang di dalamnya terdapat proses belajar dan kemampuan komunikasi matematis, dengan adanya profesionalisme dan kemampuan guru yang memadai. Profesional terlihat pada kemampuan dalam mengelola kelas dan mengajar secara efektif dan efisien, dalam arti mampu membelajarkan siswa untuk menguasai bahan pelajaran yang diberikan sesuai dengan tuntutan kurikulum.

Penerapanya dalam pembelajaran langkah-langkah pembelajaran make a match menurut Suprijono (2009) sebagai berikut:

1. Hal-hal yang perlu dipersiapkan jika pembelajaran dikembangkan dengan make a match adalah kartu-kartu. Kartu-kartu tersebut terdiri dari kartu berisi pertanyaan-pertanyaan dan kartukartu lainya berisi jawaban dari pertanyaan tersebut. 
2. Langkah berikutnya adalah guru membagi komunitas menjadi 3 kelompok.

3. Kelompok pertama merupakan kelompok pembawa karu-kartu berisi pertanyaan-pertanyaan. Kelompok kedua adalah kelompok pembawa kartu-kartu berisi jawaban-jawaban. Kelompok ketiga adalah kelompok penilai. Aturlah posisi kelompok-kelompok tersebut berbentuk huruf U. Upayakan kelompok pertama dan kedua berjajar saling berhadapan.

4. Jika masing-masing kelompok sudah berada di posisi yang telahditentukan, maka guru membunyikan peluit sebagai tanda agar kelompok pertama maupun kelompok kedua saling bergerak mereka bertemu, mencari pasangan pertanyaanjawaban yang cocok. Berikan kesempatan kepada mereka untuk berdiskusi. Ketika mereka diskusi alangkah baiknya jika ada musik instrumentalia yang lembut mengiringi kemampuan komunikasi matematis belajar mereka. Hasil diskusi ditandai oleh pasangan-pasangan antara anggota kelompok pembawa kartu pertanyaan dan anggota kelompok pembawa kartu jawaban.

5. Pasangan-pasangan yang sudah terbentuk wajib menunjukkan pertanyaanjawaban kepada kelompok penilai. Kelompok ini kemudian membaca apakah pasangan pertanyaan-jawaban itu cocok. Setelah penilaian dilakukan, aturlah sedemikian rupa kelompok pertama dan kelompok kedua bersatu kemudian memosisikan dirinya menjadi kelompok penilai. Sementara, kelompok penilai pada sesi pertama tersebut diatas dipecah menjadi dua, sebagian anggota memegang kartu pertanyaan sebagian lainnya memegang kartu jawaban. Posisikan mereka dalam bentuk huruf U. Guru kembali membunyikan peluitnya menandai kelompok pemegang kartu pertanyaan dan jawaban bergerak untuk mencari, mencocokkan, dan mendiskusikan pertanyaanjawaban. Berikutnya adalah masing-masing pasangan pertanyaan-jawaban

menunjukkan hasil kerjanya kepada penilai.

6. Perlu diketahui bahwa tidak semua siswa baik yang berperan sebagai pemegang kartu pertanyaan, pemegang kartu jawaban, maupun penilai mengetahui dan memahami secara pasti apakah betul kartu pertanyaan-jawaban yang mereka pasangkan sudah cocok. Demikian halnya bagi siswa kelompok penilai. Mereka juga belum mengetahui pasti apakah penilaian mereka benar atas pasangan pertanyaan-jawaban. Berdasarkan kondisi inilah guru memfasilitasi diskusi untuk memberikan kesempatan kepada 
seluruh siswa mengonfirmasikan hal-hal yang mereka telah lakukan yaitu memasangkan pertanyaan jawaban dan melaksanakan penilaian.

\section{CD pembelajaran}

Zaenuddin (2010) menuturkan beberapa peranan $\mathrm{CD}$ pembelajaran dalam pembelajaran bila ditinjau dari peranannya $\mathrm{CD}$ pembelajaran dalam pembelajaran khususnya pembelajaran matematika yang dikategorikan dalam tiga hal utama yaitu untuk membantu proses pemahaman siswa, membantu mengaitkan daya ingat siswa tentang konsep yang dipelajari, dan meningkatkan minat serta apresiasi siswa terhadap konsep yang dipelajarinya.

Salah satu usaha untuk memberikan variasi dalam hal pembelajaran matematika adalah dengan menggunakan media pembelajaran matematika. Media (merupakan jamak dari kata medium) adalah suatu saluran untuk komunikasi. Diturunkan dari bahasa Latin yang berarti "antara". Istilah ini merujuk kepada sesuatu yang membawa informasi dari pengirim informasi ke penerima informasi. Masuk di dalamnya antara lain: film, televisi, diagram, materi cetakan, komputer, dan instruktur (Suherman dkk, 2003)

Secara lebih khusus, pengertian media dalam proses belajar Imengajar cenderung diartikan sebagai alat-alat grafis, photografis, atau elektronis untuk menangkap, memproses, dan menyusun kembali informasi visual dan verbal. Apabila media itu membawa pesan-pesan atau informasi yang bertujuan instruksional atau mengandung maksud-maksud pengajaran maka media itu disebut media pembelajaran (Arsyad, 2011).

\section{Kemampuan Komunikasi \\ Matematis}

Menurut Eliot dan Kenney (Sumarmo, 2013) bahwa kemampuan komunikasi matematika antara lain meliputi proses-proses matematika berikut:

1. Menyatakan suatu situasi atau masalah matematik atau kehidupan sehari-hari ke dalam bentuk gambar, diagram, bahasa atau simbol matematik, atau model matematik.

2. Menjelaskan suatu idea matematik dengan gambar, ekspresi, atau bahasa sendiri secara lisan atau tulisan.

3. Membuat suat cerita bedasarkan gambar, diagram, atau model matematik yang diberikan.

4. Menyusun pertanyaan tentang konten matematik yang diberikan.

Untuk mengukur kemampuan komunikasi matematis diperlukan beberapa indikator. Sumarmo (2013) menuliskan kegiatan yang tergolong pada komunikasi matematis di antaranya adalah:

1. Menyatakan suatu situasi, gambar, diagram, atau benda nyata ke dalam bahasa, simbol, idea, atau model matematik.

2. Menjelaskan idea, situasi, dan relasi matematika secara lisan atau tulisan. 
3. Mendengarkan, berdiskusi, dan menulis tentang matematika

4. Membaca dengan pemahaman suatu representasi matematika tertulis.

5. Mengungkapkan kembali suatu uraian atau paragrap matematika dalam bahasa sendiri.

\section{METODE PENELITIAN}

\section{Lokasi Penelitian}

Penelitian tindakan kelas yang berjudul "meningkatkan kemampuan komunikasi matematis siswa melalui pembelajaran make a match berbantuan $\mathrm{CD}$ pembelajaran pada materi persamaan trigonometri sederhana" ini dilaksanakan di SMA N 1 Rowosari Kabupaten Kendal.

\section{Subjek Penelitian}

Jumlah subjek penelitian ini adalah 32 siswa kelas X SMA N 1 Rowosari Kabupaten Kendal Tahun Ajaran 2016. Karakteristik siswa pada dasarnya hampir sama (homogen), dengan latar belakang siswa yang berbeda.

Penelitian ini berlangsung selama 2 bulan, dimulai pada awal bulan September 2016 dan berakhir pada akhir Oktober 2016. Pelaksanaan penelitian dibagi ke dalam 3 siklus.

\section{Variabel Penelitian}

Variabel merupakan gejala yang menjadi fokus peneliti untuk diamati (Sugiyono, 2006: 2). Variabel dalam penelitian ini dibedakan menjadi dua, yaitu variabel independen atau variabel bebas $(\mathrm{X})$ dan variabel dependen atau variabel terikat (Y). Variabel independen adalah variabel yang nilai-nilainya tidak bergantung pada variabel lain. Sedangkan variabel dependen adalah variabel yang nilainilainya bergantung pada variabel lain. Variabel independen pada penelitian ini adalah keaktifan siswa melalui make a match berbantuan CD pembelajaran. Sedangkan variabel dependen pada penelitian ini adalah kemampuan komunikasi matematis siswa melalui make a match berbantuan CD pembelajaran materi persamaan trigonometri sederhana.

\section{Siklus Penelitian}

Penelitian ini dilaksanakan dalam 3 siklus, dan masing-masing siklus terdiri atas 4 kegiatan utama, yaitu pembuatan rencana (plan), pelaksanaan tindakan(action), pemantauan (observation), dan refleksi (reflection). Pada tahap rencana peneliti membuat persiapan. Semua kegiatan yang akan dilaksanakan dimatangkan serta penentuan alat yang akan digunakan untuk memantau tindakan yang akan akan dilakukan pada tahap tindakan, guru menyajikan pembelajaran sesuai dengan rencana yang telah dirumuskan. Bersamaan dengan pelaksanaan tindakan, peneliti melakukan pemantauan dengan menggunakan cara yang telah disepakati pada tahap perencanaan. Hasil pemantauan ini direfleksikan secara bersama untuk melihat kelebihan dan kekurangan yang akan dipergunakan dalam pelaksanaan tindakan selanjutnya. 


\section{Instrumen Penelitian}

Guna mendapatkan data penelitian yang valid dan dapat dipertanggung jawabkan, dalam penelitian ini digunakan beberapa instrumen, seperti lembar observasi, lembar catatan lapangan, dan quessioner atau angket (lembar hasil tes siswa).

\section{HASIL DAN PEMBAHASAN}

\section{Hasil Penelitian dan Pembahasan} Siklus 1

\section{Hasil Penelitian Siklus 1}

Dari pelaksanaan siklus 1, diperoleh berbagai data yaitu mengenai kemampuan komunikasi matematis, data mengenai hasil obeservasi kemampuan komunikasi matematis siswa, dan mengenai kemampuan komunikasi matematis diskusi kelompok.

a. Kemampuan komunikasi matematis siswa

Setelah dilakukan analisis data hasil tes siklus I dengan sub pokok bahasan keliling, diperoleh nilai rata-rata siswa sebesar 68,40 , siswa yang tuntas sebanyak 20 anak (60\%), siswa yang tidak tuntas sebanyak 15 anak (40\%) dengan nilai tertinggi 93 dan nilai terendah 50.

b. Hasil observasi kemampuan komunikasi matematis siswa

Pada siklus I diperoleh jumlah sekor kemampuan komunikasi matematis siswa dalam pembelajaran sebesar 27 dengan sekor rata-rata 2,7 , dengan kriteria kemampuan komunikasi matematis siswa dalam pembelajaran baik.

Dari lembar observasi siswa diproleh hal-hal sebagai berikut.

1) Siswa yang hadir sebanya- 25 .

2) Siswa yang siap mengikuı pelajaran sebanyak 20 siswa.

3) Siswa yang antusias dalam mengerjkan tugas sebanyak 18 siswa.

4) Siswa yang berani mengerjakan tugas di depan kelas sebanyak 10 siswa.

5) Siswa yang berani dalam menyajikan temuannya sebanyak 11 siswa.

6) Siswa yang terampil menulis di papan tulis sebanyak 24 siswa.

7) Siswa yang berani bertanya pada saat pembelajaran sebanyak 12 siswa.

8) Siswa yang bekerjasama dengan siswa yang lain sebanyak 21 siswa.

9) Siswa yang berdiskusi dengan kelompoknya sebanyak 19 siswa.

10) Siswa yang memberikan kesan baik saat pembelajaran berlangsung sebanyak 22 siswa.

c. Hasil observasi kemampuan komunikasi matematis dikusi kelompok

Pada siklus 1 ini diperoleh kelompok yang aktif hanya 3 kelompok, kelompok yang cukup aktif hanya ada 4 kelompok.

1) Jumlah skor untuk kelompok 1 adalah 10 dan rata-rata skor 2.0 
dengan kriteria kelompok cukup aktif.

2) Jumlah skor untuk kelompok 2 adalah 12 dan rata-rata skor 2.4 dengan kriteria kelompok cukup aktif.

3) Jumlah skor untuk kelompok 3 adalah 12 dan rata-rata skor 2.4 dengan kriteria kelompok cukup aktif.

4) Jumlah skor untuk kelompok 4 adalah 14 dan rata-rata skor 2.8 dengan kriteria kelompok aktif.

5) Jumlah skor untuk kelompok 5 adalah 14 dan rata-rata skor 2.8 dengan kriteria kelompok aktif.

6) Jumlah skor untuk kelompok 6 adalah 15 dan rata-rata skor 3.0 dengan kriteria kelompok aktif.

7) Jumlah skor untuk kelompok 7 adalah 11 dan rata-rata skor 2.2 dengan kriteria kelompok cukup aktif.

\section{Pembahasan Siklus 1}

Berdasarkan hasil tes pada siklus 1, nilai rata-rata kemampuan komunikasi matematis yang dicapai siswa adalah 68.40 dengan prosentasi $60 \%$, untuk nilai rata-rata kemampuan komunikasi matematis yang dicapai sudah mencapai indikator keberhasilan yang ditetapkan tetapi untuk prosentase masih jauh di bawah indikator keberhasilan yang ditetapkan. Hal ini terjadi karena disebabkan beberapa faktor diantaranya adalah sebagai berikut.

a. Siswa belum memahami peran dan tugasnya dalam bekerja kelompok karena belum terbiasa dengan model pembelajaran yang diterapkan.

b. Interaksi antar siswa belum berjalan dengan baik karena siswa belum terbiasa untuk menyampaikan pendapatnya kepada sesama teman lainnya dalam menyelesaian masalah.

c. Adanya siswa yang pasif dan menggantungkan permasalahan yang dihadapi kepada kelompoknya.

d. Dalam diskusi kelompok hanya didominasi oleh siswa yang pandai.

e. Pada saat penyajian hasil karya kelompok hanya beberapa kelompok saja yang menyajikan hasil karya kelompoknya karena waktu yang tida memungkinkan.

f. Guru belum bisa mengorganisasikan waktu dengan baik, karena waktu untuk mengerjakan LKS terlalu lama sehingga waktu unutk presentasi hasil karya kelompo terbatas.

g. Guru dalam memberikan bimbingant tidak merata, guru hanya memberikan bimbingan pada kelompok yang aktif bertanya saja.

Uraian di atas menyatakan bahwa pada siklus I indikator keberhasilan belum tercapai. Oleh karena itu perlu adanya sesuatu tindakan pada siklus II agar kemampuan komunikasi matematis siswa dapat ditingkatkan dan mencapai indikator keberhasilan yang ditetapkan. 


\section{Hasil Penelitian dan Pembahasan}

\section{Siklus 2}

\section{Hasil Penelitian Siklus 2}

Dari pelaksanaan siklus 2, diperoleh berbagai data yaitu mengenai kemampuan komunikasi matematis siswa, data mengenai hasil obeservasi kemampuan komunikasi matematis siswa, dan mengenai kemampuan komunikasi matematis diskusi kelompok.

a. Kemampuan komunikasi matematis siswa (tes)

Setelah dilakukan analisis data hasil tes siklus II dengan materi pokok luas persegi panjang, diperoleh nilai rata-rata siswa sebesar 72.31, siswa yang tuntas sebanyak 30 anak (85.71\%), siswa yang tidak tuntas sebanyak 5 anak (14.29\%) dengan nilai tertinggi 93 dan nilai terendah 60 .

b. Hasil observasi kemampuan komunikasi matematis siswa Pada siklus 2 diperoleh jumlah sekor kemampuan komunikasi matematis siswa dalam pembelajaran sebesar 32 dengan sekor rata-rata 3,2, dengan kriteria kemampuan komunikasi matematis siswa dalam pembelajaran cukup.

Dari lembar observasi siswa diproleh hal-hal sebagai berikut.

1) Siswa yang hadir sebanyak 35 .

2) Siswa yang siap mengikuti pelajaran sebanyak 20 siswa.

3) Siswa yang antusias dalam mengerjkan tugas sebanyak 30 siswa.

4) Siswa yang berani mengerjakan tugas di depan kelas sebanyak 24 siswa.
5) Siswa yang berani dalam menajikan temuannya sebanyak 18 siswa.

6) Siswa yang terampil menulis di papan tulis sebanyak 28 siswa.

7) Siswa yang berani bertanya pada saat pembelajaran sebanyak 17 siswa.

8) Siswa yang bekerjasama dengan siswa yang lain sebanyak 29 siswa.

9) Siswa yang berdiskusi dengan kelompoknya sebanyak 25 siswa.

10) Siswa yang memberikan kesan baik saat pembelajaran berlangsung sebanyak 35 siswa.

c. Hasil observasi kemampuan komunikasi matematis dikusi kelompok

Pada siklus 2 ini diperoleh kelompok yang sangat aktif hanya 2 kelompok, kelompok yang aktif hanya ada 5 kelompok.

Dari lembar observasi kemampuan komunikasi matematis diskusi kelompok diperoleh hal-hal sebagai berikut.

1) Jumlah skor untuk kelompok 1 adalah 13 dan rata-rata skor 2.6 dengan kriteria kelompok aktif.

2) Jumlah skor untuk kelompok 2 adalah 14 dan rata-rata skor 2.8 dengan kriteria kelompok aktif.

3) Jumlah skor untuk kelompok 3 adalah 14 dan rata-rata skor 2.8 dengan kriteria kelompok aktif.

4) Jumlah skor untuk kelompok 4 adalah 16 dan rata-rata skor 3.4 dengan kriteria kelompok sangat aktif. 
5) Jumlah skor untuk kelompok 5 adalah 15 dan rata-rata skor 3.0 dengan kriteria kelompok aktif.

6) Jumlah skor untuk kelompok 6 adalah 17 dan rata-rata skor 3.4 dengan kriteria kelompok aktif.

7) Jumlah skor untuk kelompok 7 adalah 14 dan rata-rata skor 2.8 dengan kriteria kelompok aktif.

\section{Pembahasan Siklus 2}

Berdasarkan hasil tes pada siklus 2, nilai rata-rata kemampuan komunikasi matematis yang dicapai siswa adalah 75 dengan prosentasi $84.62 \%$. Kemampuan komunikasi matematis tersebut sudah mencapai indikator keberhasilan yang ditetapkan yaitu sekurang-kurangnya $75 \%$. Hal ini disebabkan oleh beberapa faktor diantaranya adalah sebagai berikut.

a. Siswa sudah mulai terbiasa dengan bekerja secara kelompok.

b. Keberanian siswa untuk interaksi antar siswa berjalan dengan baik karena siswa mulai terbiasa untuk menyampaikan pendapatnya kepada sesama teman lainnya dalam menyelesaian masalah.

c. Siswa mulai aktif dan tahu akan tugasnya sehingga tidak menggantungkan permasalahan yang akan dihadapi kepada teman dalam kelompoknya.

d. Karena siswa sudah aktif dalam dikusi kelompok maka guru dapat membimbing siswa pada saat diskusi secara merata sehingga diskusi dapat berjalan efektif.

e. Guru sudah dapat mengorganisasikan waktu dengan baik.
Pada siklus II pelaksanaan pembelajaran make a match berbantuan CD pembelajaran sudah efektif. Proses pembelajaran yang dilaksanakan guru pada siklus 2 sudah memenuhi komponen-komponen dalam pembelajaran make a match berbantuan CD pembelajaran. Menurut Suyitno (2004: 9) model pembelajaran make a match mempunyai 7 langkah yaitu:

1. Kembangkan pemikiran, bahwa anak perlu mengkonstruksi sendiri pengetahuannya (belajar secara mandiri);

2. Lakukan kegiatan inkuari untuk semua topik;

3. Ungkap rasa ingin tahu siswa dengan bertanya;

4. Ciptakan masyarakat belajar;

5. Hadirkan model untuk contoh pembelajaran;

6. Lakukan refleksi di akhir pertemuan;

7. Lakukan penilaian yang sebenarnya dengan berbagai cara.

Berdasarkan hasil observasi guru, siswa, kemampuan komunikasi matematis diskusi kelompok dan hasil tes pada siklus II dapat dievaluasi bahwa langkah-langkah yang telah diprogramkan dan dilaksanakan mampu mencapai tujuan yang diharapkan dalam penelitian.

Dengan demikian pembelajaran make a match berbantuan CD pembelajaran dapat meningkatkan kemampuan komunikasi matematis siswa kelas SMA N 1 Rowosari Kabupaten Kendal Tahun Pelajaran 
2016/2017 materi persamaan trigonometri sederhana. Secara umum uraian di atas menunjukkan bahwa ada peningkatan kemampuan komunikasi matematis siswa dalam kegiatan belajar mengajar dengan menggunakan model pembelajaran make a match berbantuan CD pembelajaran pada siswa kelas SMA N 1 Rowosari Kabupaten Kendal.

\section{Pembahasan Keseluruhan siklus 1 dan siklus 2}

Pembahasan dalam penelitian ini meliputi pembahasan tentang pembelajaran make a match berbantuan $\mathrm{CD}$ pembelajaran materi persamaan trigonometri sederhana untuk meningkatkan kemampuan komunikasi matematis siswa kelas $\mathrm{X}$ SMA N 1 Rowosari Kabupaten Kendal tahun 2016/2017. Berdasarkan hasil tes kemampuan komunikasi matematis pada siklus 1 dan 2 yaitu pada siklus 1 diperoleh rata-rata siswa sebesar 68,40. Banyaknya siswa yang memperoleh nilai lebih dari atau sama dengan $75(\geq 75)$ atau dapat dikatakan tuntas sebanyak 20 siswa atau $60 \%$. Jumlah tersebut belum mencapai target dalam peningkatan kemampuan komunikasi matematis siswa, jadi perlu diadakan siklus 2 untuk mencapai target yang diinginkan. Berdasarkan hasil tes siklus 2, diperoleh rata-rata siswa sebesar 72,31. Banyaknya siswa yang memperoleh nilai lebih dari atau sama dengan $75(\geq 75)$ atau dapat dikatakan tuntas sebanyak 30 siswa atau $85,71 \%$. Jumlah tersebut telah mencapai target dari indikator keberhasilan pembelajaran yaitu banyaknya siswa yang yang memperoleh nilai lebih dari atau sama dengan $75(\geq 75)$ atau dapat dikatakan tuntas minimal $75 \%$ dari banyaknya siswa kelas $\mathrm{X}$ dan tidak perlu diadakan tindakan lebih lanjut.

Berdasarkan hasil observasi kemampuan komunikasi matematis siswa pada siklus 1 dan 2 yaitu pada siklus 1 hasil penilaian observasi terhadap kemampuan komunikasi matematis siswa diperoleh skor ratarata 2,7 dengan kriteria kemampuan komunikasi matematis siswa dalam pembelajaran baik. Hasil penilaian tersebut belum mencapai target, jadi perlu diadakan siklus 2 untuk mencapai target yang diinginkan. Berdasarkan hasil observasi kemampuan komunikasi matematis siswa pada siklus 2 hasil penilaian observasi terhadap kemampuan komunikasi matematis siswa diperoleh skor rata-rata 3,2 dengan kriteria kemampuan komunikasi matematis siswa dalam pembelajaran sangat baik. Hasil penilaian tersebut telah mencapai target dari indikator keberhasilan pembelajaran jadi dapat dikatakan tuntas dan tidak perlu diadakan tindakan lebih lanjut.

Berdasarkan hasil observasi kemampuan komunikasi matematis melalui diskusi kelompok pada siklus 1 dan 2, yaitu pada siklus 1 hasil penilaian observasi terhadap kemampuan komunikasi matematis diskusi kelompok diperoleh skor ratarata 2,50 dengan kriteria kemampuan komunikasi matematis melalui diskusi kelompok cukup baik. Hasil penilaian tersebut belum mencapai target, jadi 
perlu diadakan siklus 2 untuk mencapai target yang diinginkan. Berdasarkan hasil observasi kemampuan komunikasi matematis diskusi kelompok pada siklus 2, hasil penilaian observasi terhadap kemampuan komunikasi matematis melalui diskusi kelompok diperoleh skor rata-rata 3,10 dengan kriteria kemampuan komunikasi matematis melalui diskusi kelompok baik. Hasil penilaian tersebut telah mencapai target dari indikator keberhasilan pembelajaran jadi dapat dikatakan tuntas dan tidak perlu diadakan tindakan lebih lanjut. Secara umum proses pembelajaran yang berlangsung disetiap siklus sudah berjalan dengan baik, hal ini ditunjukkan dengan semua tahapan yang ada dalam pembelajaran melalui make a match berbantuan $\mathrm{CD}$ pembelajaran sudah dilaksanakan dengan baik.

Dari pembahasan di atas menunjukkan bahwa indikator keberhasilan telah tercapai. Ada peningkatan kemampuan komunikasi matematis siswa dalam kegiatan belajar melalui make a match berbantuan CD pembelajaran pada materi persamaan trigonometri sederhana siswa kelas X SMA N 1 Rowosari Kabupaten Kendal.

\section{SIMPULAN DAN SARAN}

\section{Simpulan}

Berdasarkan penelitian dan pembahasan, dapat ditarik simpulan bahwa melalui pembelajaran make a match berbantuan CD pembelajaran dapat meningkatkan kemampuan komunikasi matematis siswa materi persamaan trigonometri sederhana kelas X.

\section{Saran}

Berdasarkan simpulan disarankan pada guru mata pelajaran matematika agar menerapkan model pembelajaran make a match berbantuan $\mathrm{CD}$ pembelajaran dapat meningkatkan kemampuan komunikasi matematis siswa.

\section{DAFTAR PUSTAKA}

Arsyad, A. (2011). Media Pembelajaran. Jakarta: Raja Grafindo Persada.

Sugiyanto. (2010). Metode Penelitian Pendidikan. Bandung: Alfabeta.

Suherman, E., dkk. (2003). Strategi Pembelajaran Matematika Kontemporer. Bandung: JICA IMSTEP Universitas Pendidikan Indonesia.

Sumarmo, U. (2013). Kumpulan Makalah Berpikir dan Disposisi Matematik serta Pembelajarannya. Bandung: FMIPA UPI

Supridjono, A. (2009). Matematika Gemar Berhitung 3B. Solo: PT Tiga Serangkai Pustaka Mandiri.

Zaenuddin. (2010). Penggunaan Balok Garis pada Operasi Hitung Bilangan Bulat Bilangan Jurnal Pendidikan Batang Barkembang. http://redaksi jurnalpendidikan.blogspot.com/2 010/03/penggunaan-balok-garisbilangan-pada-bilangan-

bulat.htm (diunduh 22 Agustus 2010). 
